Jobbágy Zoltán ${ }^{1 \odot}$

\title{
Charles Edward Callwell és a kisháborúk ciklikus természete
}

\section{Charles Edward Callwell and the Cyclical Nature of Small Wars}

\begin{abstract}
Absztrakt
Jelen tanulmányban a szerző a nemzetközi rendszer ciklikusságát alapul véve egy Magyarországon kevésbé ismert brit klasszikus, Charles Edward Callwell kisháborúkra vonatkózó föbb megfigyeléseit mutatja be. Tanulmányában egyértelmüsití, hogy Callwell kisháborúkra vonatkozó leírása nagymértékben egyezik a 21. század első két évtizedében kirobbant konfliktusok föbb sajátosságaival. Callwell müvében egyértelmüen megmutatkozik hogy a szimmetrikus és az aszimmetrikus jelleg, a magas és az alacsony intenzitás, az állami és a nem állami szereplök, a reguláris és az irreguláris haderök, valamint a hagyományos és a nem hagyományos hadviselés keveredése magában hordozza úgynevezett szürkezónás állapotok kialakulásának lehetöségét.
\end{abstract}

Kulcsszavak: ciklikusság, nemzetközi rendszer, kisháború, Callwell, reguláris erök

\begin{abstract}
In this study the author, based on the cyclical nature of the international system, introduces the major observations on small wars of a British classic, Charles Edward Callwell who is not very much known in Hungary. He makes it clear that the description of Callwell on small wars bears, to a great extent, similarities with conflicts erupted in the first two decades of the $27^{15 t}$ century. Callwell's work explains that the combination of symmetry and asymmetry, high and low intensity, state and non-state actors, regular and irregular forces, traditional and non-traditional warfare always contain the possibility of so-called gray zone situations.
\end{abstract}

Keywords: cyclicity, international system, small war, Callwell, regular forces 


\section{Bevezetés}

Kondratieff The Long Waves in Economic Life címü, 1935-ben megjelent és azóta klasszikussá vált tanulmányában azt részletezte, hogy a tőkés gazdasági rend fejlődésének dinamikája nem egyszerü és lineáris, hanem hullámszerü, összetett, és leírható különböző hosszúságú ciklusokkal.²

A ciklikus mozgást mint tudományos megközelítést Modelski a The Long Cycle of Global Politics and the Nation-State címen 1978-ban közölt tanulmányában kiterjesztette a nemzetközi rendszerre. Megállapítása szerint a nemzetközi rendszer fejlődését, valamint különböző változásait ciklusok visszatérő mintái határozzák meg. A ciklikusság eredményeként a nemzetközi rendszer mindig visszatér egy korábbi, akár kiindulásinak is nevezhető állapotába. Modelski szerint a ma ismert globális politikai rendszer valamikor az 1500-as évek környékén született meg, és különböző formában, jól-rosszul azóta is meghátározza a Föld mindennapjait. ${ }^{3}$ Ez a megfigyelés egybeesik azzal a történészi véleménnyel, amely szerint Európa egy lényegében több száz éves háborút vezetve a világ ellen a 20 . század elejére megszerezte a globális hatalmat. ${ }^{4}$

\section{A ciklikusság következményei}

A ciklikusság elvének nem mond ellent, hogy a különböző tanulmányok és stratégiák a folyamatosan változó biztonsági környezet összetett kihívásait egyedülálló és egyedi jelenségekként írják le. A globalizált világ állandóvá vált társadalmi és gazdasági megrázkódtatásai, a növekvő biztonsági kockázatok és egyéb bizonytalanságok az államot, a kormányzatot és a fegyveres erőket rendkívüli feladatokkal szembesítik, ahogy szembesítették a korábbi korokban is. ${ }^{5}$ A formálódó, több pólusúvá váló globalizáció, a nemzetközi szereplők kapcsolatait befolyásoló szabályok átalakítására való törekvés, a biztonsági kihívások összetettsége növekvő bizonytalanságot eredményez és eredményezett mindig is a történelemben. ${ }^{6}$

A ciklikusság egyértelmüsíti, hogy a nemzetközi rendszer müködésére befolyással bíró biztonsági környezet sajátosságai nem feltétlenül változnak. Az elmúlt néhány száz év során ezek a sajátosságok leginkább ellentétpárokat tartalmazó töréspontok mentén foghatók meg a legjobban. A töréspontokban egyszerre kell és kellett kezelni a konfliktusok szimmetrikus és aszimmetrikus jellegét, alacsony és magas intenzitását, az állami és nem állami szereplők meglétét, a reguláris és irreguláris haderők szembenállását, valamint a hagyományos és nem hagyományos hadviselés jelentette

Nikolai D. Kondratieff: The Long Waves in Economic Life. The Review of Economics and Statistics, 17. (1935), 6. 10-115.

George Modelski: The Long Cycle of Global Politics and the Nation-State. Comparative Studies in Society and History, 20. (1978), 2. 214-15.

4 Ian Morris: War! What is it Good For? Conflict and Progress of Civilization from Primates to Robots. Farrar, Straus and Giroux, 2014. 165-234.

5 Nemzeti Közszolgálati Egyetem Kutatási, Fejlesztési és Innovációs Stratégia 2016-2020. Budapest, Nemzeti Közszolgálati Egyetem, 2016. 34.

6 1163/2020. (IV. 21.) Korm. határozat Magyarország Nemzeti Biztonsági Stratégiájáról. 1. sz. melléklet: Magyarország Nemzeti Biztonsági Stratégiája „Biztonságos Magyarország egy változékony világban”. Magyar Közlöny, CXLVII (2020), 81. 2101-2104. 
kihívásokat. A konfliktusok közös vonása, hogy megjelenik bennük a katonai és a nem katonai eszközök vegyes, divatos kifejezéssel élve hibrid alkalmazásának változatos kombinációja. Az ilyen konfliktusok egyértelmű következménye, hogy olyan szürkezónás állapotok kialakulását eredményezhetik, amelyek a hagyományos értelemben vett nagy háborútól eltérnek. Nehezen áttekinthető jellegük miatt kirobbanásuk tér- és időbeli elörejelezhetősége pedig alacsony. ${ }^{7}$

Szürkezónás jellegük miatt a konfliktusokban a hangsúly az intézményi térből a társadalmi és az egyéni tér felé mozdulhat el. Megjelenhet bennük a terror és az ellenterror, valamint az ellenség teljes megsemmisítése. Az erőszak korlátlan jelleget ölthet, amely a katonai tevékenységek olyan hagyományos alapját kérdőjelezi meg, mint a háború és a béke különválasztása, a katona és a civil megkülönböztetése, az ellenség és a bünöző elhatárolása, valamint az államok közötti és az államon belüli háború szétválasztása. Az eredmény a tér-idő hagyományos hadviseléstől eltérő értelmezése, a meglévő társadalmi szerkezet szétzúzása, a bel- és a külpolitikai környezet összemosása, valamint a hadviselést támogató technikai-ipari háttér átalakítása. ${ }^{8}$

Az ilyen válságok nem feltétlenül zárják ki a hagyományos hadműveleti elvek és megfontolások érvényesülését, azonban azok közvetett vagy ellentmondásos módon való megjelenését eredményezhetik. ${ }^{9}$

\section{Jelentős hangsúlyeltolódás}

A bipoláris világrend megszűnését követő három évtized biztonságpolitikai eseményei következtében jelentős hangsúlyeltolódás következett be a háború megvívására és a hadviselésre vonatkozó ismeretekben. ${ }^{10}$

Az elmúlt évtizedek különböző fegyveres konfliktusai egyértelművé tették, hogy a háború hagyományos értelemben vett nagyháborús megközelítése csak szűk tudományos mozgásteret biztosít. Az elmúlt évtizedek irreguláris, aszimmetrikus és alacsony intenzitású sajátosságokat magán viselő, lényegében kisháborús" konfliktusai katonai valósággá váltak a NATO vezette koalíciós erők számára Irakban

1163/2020. (IV. 21.) Korm. határozat Magyarország Nemzeti Biztonsági Stratégiájáról. 1. sz. melléklet: Magyarország Nemzeti Biztonsági Stratégiája „Biztonságos Magyarország egy változékony világban” 2020. 2107-2112; Jobbágy Zoltán: A felkelők elleni műveletekről: Egy elfeledett klasszikus: Bernardo de Vargas Machuca. Honvédségi Szemle, 141. (2013), 2. 15; Porkoláb Imre: Szervezeti adaptáció a Magyar Honvédségben: küldetésalapú vezetés 2.0 a digitális transzformáció korában. Honvédségi Szemle, 147. (2019), 1. 3-12.

8 Carl Schmitt: The Theory of the Partisan, A Commentary/Remark on the Concept of the Political. Berlin, Duncker \& Humblot, 1963. 32-38.

9 Friedrich August Freiherr von der Heydte: Modern Irregular Warfare in Defense Policy and as a Military Phenomenon. New York, New Benjamin Franklin House, 1986. 16-22; Jobbágy Zoltán: David Galula és a felkelés ellenes múveletek elmélete és gyakorlata francia megközelítésben. Hadtudományi Szemle, 10. (2017), 4. 20-24; Bakos Csaba Attila: Hagyományostól eltérő hadviselés, hagyományostól eltérő vezetésszemlélet. Társadalom és Honvédelem, 19. (2015), 3. 41-44; AJP-3.4.4 (A) Allied Joint Doctrine for Counter-Insurgency. Brüsszel, NATO Standardization Agency, 2016. A-1-A-3.

10 Ujházy László: Felkészítés a NATO összhaderőnemi kötelékei parancsnokságain rendszeresített beosztásokra. Honvédségi Szemle, 62. (2008), 1. 30.

11 Az angol és a francia nyelvterületen a külön írt small war és a petite guerre kifejezések terjedtek el. Német nyelvterületen mind a kleiner Krieg, mind a Kleinkrieg kifejezések használatosak. Magyarul használják a kisháború és a kis háború kifejezéseket is. A tanulmányban a szerző a kisháború irásmódot használja, azaz egybeírja. 
és Afganisztánban. A kisháború kifejezés mellett a háború ezen megjelenési formájára a nemzetközi szakirodalomban olyan elnevezések is léteznek, mint aszimmetrikus, gerilla, partizán, forradalmi, alacsony intenzitású, irreguláris, korlátozott, modern, nem hösies, kényelmetlen, nem Clausewitz-i, nem háromsági vagy törzsi. A nagy háborútól eltérően a kisháború mindig partikuláris, kontextus- és korszakfüggő. Megjelenési formáját és egyéb sajátosságait nagyban meghatározza a szemben álló felek között meglévő társadalmi, gazdasági, technikai, kulturális és katonai különbség. A kisháború irreguláris, aszimmetrikus és alacsony intenzitású sajátosságából kifolyólag tudományos szempontból nehezebben kategorizálható. Kevesebb lehetőséget biztosít az általánosításra és szükebb mozgásteret enged a tudományos rendszerezésnek. ${ }^{12}$

A töréspontok mentén kirobbanó kisháborúkat a NATO szövetséges összhaderönemi kiadványai nem 5. cikkely szerinti válságkezelö müveletekként, azon belül is felkelésellenes müveletként határozzák meg. ${ }^{13}$ Az ilyen jellegü müveletek sajátosságainak jobb megértése érdekében az Amerikai Egyesült Államok hadereje 2006-ban kiadta az FM 3-24 Counterinsurgency, felkelésellenes müveletekre vonatkozó tábori kézikönyvet, amelyet 2014-ben kicsit más címmel és megújított tartalommal ismét kiadtak. ${ }^{14}$ Némi késéssel, 2011-ben a NATO is kiadta az AJP-3.4.4 Allied Joint Doctrine for Counterinsurgency (COIN) szövetséges összhaderönemi doktrínát, amelyet 2016-ban szintén követett egy átdolgozott változat. ${ }^{15}$

A nemzetközi rendszer ciklikussának további bizonyítéka, hogy az ellentétpárok jobb megértése érdekében újrafelfedeztek olyan közismert klasszikusokat, mint Che Guevara, Mao Ce Tung, David Galula és Roger Trinquier. Elötérbe kerültek olyan kevésbé ismert szerzők is, mint a kanadai William S. G. Heneker, a német/dán Johann von Ewald, valamint a jelen tanulmányban bemutatásra kerülő brit C. E. Callwell. ${ }^{16}$ A ciklikusságot támasztja alá az a tény is, hogy minden társadalmi haladás ellenére a világ népességének jelentős része úgy él állami keretekben, hogy annak nem aktív részese. Százmilliók élnek a társadalmak különböző szegmenseiben továbbra is olyan törzsi kötelékekben, amelyeket nem lehet politikai entitásként értelmezni. ${ }^{17}$

A kisháborúk megvívása katonai szakmai szempontból nem feltétlenül attraktív. A szűk értelemben vett katonai tényezők mellett egyéb, nem katonai tényezők válhatnak fontossá, meghatározóvá. A szemben álló felek közötti különbségek miatt a győzelem nem ad feltétlenül okot a büszkeségre, a vereség pedig kifejezetten kínos. ${ }^{18} \mathrm{~A}$ felkeléseket tárgyaló katonai szakirodalomban meghatározó szerepet tölt be az indokínai

12 Charles Callwell E.: Small Wars: Principles and Practice. General Staff - War Office, 1906. 21.

13 AJP-3.4.4 Allied Joint Doctrine for Counterinsurgency (COIN). NATO Standardization Agency, Brüsszel, 2011; AJP3.4.4 (A) Allied Joint Doctrine for Counter-Insurgency. (2016) i. m.

14 Lt. Col. John Nagl "The U.S. Army/Marine Corps Counterinsurgency Field Manual".; FM 3-24/MCWP 3-33.5: Counterinsurgency. Headquarters, Department of the Army, Washington, 2006; FM 3-24/MCWP 3-33.5: Insurgencies and Countering Insurgencies. Headquarters, Department of the Army, Washington, 2014.

15 AJP-3.4.4 Allied Joint Doctrine for Counterinsurgency (COIN); AJP-3.4.4 (A) Allied Joint Doctrine for Counter-Insurgency.

16 Jobbágy (2013) i. m. 15-18; Lásd még Boda Mihály: A kisháború etikája. In Harangi-Tóth Zoltán (szerk.): $A$ „kisháborúk” és a könnyü csapatok harcászata (1792-1918). Elmélet, etika és a gyakorlat. Hadtörténelem egyetemi jegyzet. Budapest, Nemzeti Közszolgálati Egyetem, 2019. 7-50.

17 Tribes still matter, how global leaders tap into diaspora networks. The Economist, 2011. január 22.

18 Jobbágy (2013) i. m. 15-18 
és az algériai háborúk tapasztalatait feldolgozó David Galula (1919-1967), akinek munkássága a fent említett FM- és AJP-kiadványokban egyértelműen visszaköszön. ${ }^{19}$

Mind az amerikai FM-, mind a szövetséges AJP-kiadványok elönyben részesítik a francia klasszikust, és még az említés szintjén sem foglalkoznak a kisháború olyan brit klasszikusával, mint C. E. Callwell. Ez annál is érdekesebb, mivel Callwell idejében a brit haderő egy alapvetően a kisháborúk megvivásásra sikeresen szakosodott szervezet volt. Az elmúlt évszázadok során feladatrendszerében az európai hatalmak vetélkedésében való részvétel mellett hangsúlyosan jelent meg a birodalmi terjeszkedés támogatása, majd a birodalom belső rendjének folyamatos biztosítása. ${ }^{20} \mathrm{Az}$ esetenkénti vereségektől függetlenül, technológiai és egyéb fölényüknek köszönhetően a viszonylag kis brit expedíciós erők képesek voltak a legegyszerübb harceljárások alkalmazása esetén is a lényegesen nagyobb ellenséges erők felett akár mészárlásokba fulladó győzelmeket aratni..21

\section{Brit gyarmati terjeszkedés}

A 20. században sikerrel megvívott két világháború, valamint a győztes oldalon befejezett hidegháború éles ellentétben állt a brit haderő önmagáról alkotott képével. A dicső és hosszú 19. századot váltó 20 . század során a brit haderő folyamatosan kereste az egyensúlyt az önmagáról alkotott gyarmati kisháborús kép és a globális szembenállás jelentette nagy háborús valóság között. Jó példa erre, hogy John Strawson vezérőnagy az 1970-es években a brit szárazföldi haderő vezérkari főnökeként említést tett a statikus hidegháborús szerep miatt a Brit Fegyveres Erőknél tapasztalható katonai unalomról. A magas intenzitású hadmúveletek fontosságának hangsúlyozása nem változtatta meg brit haderő gyarmati szemléletét és az abban továbbélő strukturális örökséget. ${ }^{22}$

A kisháború brit megközelítése két alapvető tényező mentén érthető meg, úgymint a minimális katonai erő alkalmazása, valamint a civil-katonai kapcsolatok megléte. A minimális katonai erő alkalmazása nagyon mélyen gyökeredzik a brit haderőben, és alapvetően a brit politikai kultúrára és a politikai pragmatizmusra vezethető viszsza. Nagy-Britanniában a 20. század elejétől az egyre erősebbé és befolyásosabbá váló középosztály révén elterjedt a liberalizmus és a filantrópia. A brit politikai elit és egyes befolyásos véleményformálók szükségesnek érezték, hogy az addigi brit birodalmi terjeszkedés gyakorlatától eltérjenek, mivel a politikai kultúra egyre jobban a humanitárizmus befolyása alá került. A közéletet áthatotta a becsület és a kötelesség

19 Terence Peterson: Myth-Busting French Counterinsurgency. War on the Rocks/Texas National Security Review, 2015. december 3.; Geoff Demarest: Let's Take the French Experience in Algeria Out of U.S. Counterinsurgency Doctrine. Military Review, 88. (2010), 4. 19-21.

20 Rod Thornton: Historical Origins of the British Army's Counterinsurgency and Counterterrorist Techniques. In Theodor H. Winkler - Anja H. Ebnöther - Matts B. Hansson (szerk.): Combating Terrorism and Its Implications for the Security Sector. Swedish National Defence College, 2005. 26.

21 William C. G. Heneker: Bush Warfare - The Early Writings of General Sir William C. G. Heneker, KCMG, DSO. Edited with New Material and Introduction by Major Andrew B. Godefroy, Directorate of Land Concepts and Designs. Department of National Defence, Canada, 2009. 22-51.; John Ellis: The Social History of the Machine Gun. New York, Pantheon Books, 1975. 86-87.

22 Thornton (2005) i. m. 26-30. 
eszméje, a mindennapokat pedig átszőtte a romanticizmus. A brit haderö zömében úriemberekből álló tisztikarában egyre inkább megjelent a lovagiasság eszméje, így a brit befolyás növelése mellett fontosnak tartották a brit értékek közvetítését is. A lovagiasság eszméjét terjesztette a viktoriánus korszak előkelő, bentlakásos iskoláinak rendszere is, amely a brit tisztikar fontos utánpótlási bázisaként alapvetőn a jellemet és nem az intellektust fejlesztette. ${ }^{23}$

Ezek az elvek lassan az egész társadalmat áthatották, és minden formában terjesztésre kerültek az írott és az íratlan média, valamint a felsőbb rétegek társadalmi példamutatása révén. Amennyiben ezeket az értékeket a katonák megsértették és a társadalmi elvárástól eltérően viselkedtek, büntetésre számíthattak. Néhány szomorú és sajnálatos esetet leszámítva azonban kijelenthető, hogy a brit hadsereg által alkalmazott módszereket áthatotta fair play iránti igénynek való egyfajta megfelelés, valamint a különböző mocskos trükköktől való idegenkedés. Az elvek a brit katonákat folyamatosan figyelmeztették arra, hogy fö feladatuk az ellenség megsemmisitése helyett az átmeneti zavargások elnyomása, amely során az alkalmazott erőnek mindig arányosnak kellett lennie a feladattal. Az arányos erő alkalmazásával kapcsolatos döntések meghozatala pedig a helyi parancsnok dolga volt. ${ }^{24}$

A minimális katonai erő alkalmazásának másik oka a politikai pragmatizmus, mivel a kis brit haderő nem volt képes a birodalmat csak katonai eszközökkel fenntartani. A britek az összes sikeres birodalomépítőhöz hasonlóan megértették, hogy a tartós fennmaradás az elnyomás elviselhető szinten tartásában rejlik. A birodalom rendjét fenn kellett tartani, egyes csoportokat, törzseket, etnikumokat meg kellett fékezni, másoknak pedig bízni kellett abban, hogy szükség esetén a brit erők megvédik. Túlzott katonai erő alkalmazása elidegenítette volna a semleges/lojális elemeket, növelte volna az ellenséges elemek számát, sokáig tartó keserűséget okozott volna, valamint tartós elkeseredettséget hagyott volna hátra. A túlzott erőszaktól való eltekintésnek további hozadéka is volt, mivel az így könnyebben kiépíthető információs hálózat erötöbbszörözőnek bizonyult, és sok esetben az erők megóvása szerepét is betöltötte. ${ }^{25}$

Természetesen a minimális katonai erő alkalmazásának elve nem volt elképzelhető hatékony és jól működő civil-katonai kapcsolatok nélkül. Az együttműködés alapja a bizalom volt: mindkét fél oldja meg úgy a feladatot, hogy az ne hozzon szégyent a Londonban székelő kormányzatra. A brit tisztek alapvetően sikeresen múködtek együtt a birodalmi tisztviselőkkel, és az esetek többségében a tisztviselők iránymutatását követték. Megértették, hogy a siker megköveteli a civil iránymutatást, mivel katonai erővel lehet kezelni a tüneteket, de az okok felszámolásához civil közigazgatás szükséges. Nem szabad eltekinteni attól a ténytöl sem, hogy mind a katonatisztek, mind a civil tisztviselők ugyanazon társadalmi csoportból jöttek, és ugyanazokat az iskolákat végezték. A civil-katonai kapcsolatok brit rendszere megkövetelte, hogy a brit tiszt a jó döntés meghozatala érdekében rendelkezzen fejlett politikai érzékkel, hallgasson más emberek véleményére, és legyen kész a problémákat megtárgyalni. Ez a közös háttér jelentette kapcsolati rendszer a mai napig folyamatos megerősítést

\footnotetext{
Thornton (2005) i. m. 31-36.

Thornton (2005) i. m. 37-40.

25 Thornton (2005) i. m. 41-42; Krishnan S. Mani: Jallianwala Bagh Massacre - Bitter Reminder of Indian History. South Asian Law and Economics Review, 3. (2018), november. 132-159.
} 
kap a meglévő formális/informális átfedésekből, valamint a közösen szerzett tapasztalat megosztásából. A brit haderő a kisháborúkat civil összefüggésben közelítette meg és értelmezte, amelyben a politika soha nem volt türelmetlen, és nem követelt gyors eredményeket. Természetesen a civil-katonai kapcsolatok brit rendszere sem volt mindig problémamentes, a katonákat esetenként akár magukra is hagyhatták. Ennek ellenére elmondható, hogy a politikai döntéshozók bíztak a tisztek szakmaiságában és felkészültségében, akik szintén bíztak az alárendeltek fegyelmezettségében és kiképzettségében. ${ }^{26}$

\section{Callwell és a Small Wars}

A nemzetközi rendszer ciklikusságának elméletét erősíti Alvin Toffler társadalomtudós és neves futurológus is. Egyik legjelentősebb könyvében, $A$ harmadik hullám címüben részletezte az USA-ban az 1970-es években egyre nyilvánvalóbbá váló gazdasági és társadalmi átrendeződést, és az emberiség előtt álló lehetséges jövő(ket) vizsgálta. Szerinte a nemzetközi rendszer egy mindent átalakító globális változás előtt áll, amelynek eredményeként bizonyos szempontból visszatérhet egy korábbi állapotába. A könyvében a változás mozgatórugóit vázolta fel logikusan, különböző tendenciákat és irányokat meghatározva. ${ }^{27}$

Toffler szerint a nagy természettudományi felfedezések eredményeként kialakult, az ipari forradalom eredményeként meghatározóvá vált, és a fejlett ipari országokat egyre jobban átformáló müködési elvek, úgymint a szabványosítás (standardization), a szakosodás (specialization), az összehangolás (synchronization), az összpontosodás (concentration), a szélsőértékesítés (maximization) és a központosítás (centralization) folyamatosan veszítenek erejükbool. ${ }^{28} \mathrm{~A}$ ciklikusság egyébként Clausewitznél is megjelenik, mivel $A$ háborúról című fő múvében egyértelműen kijelentette, hogy a harc megvívásának korábbi módjai ismét felbukkanhatnak. A nemzetközi rendszer ciklikussága egyértelművé teszi, hogy a kisháború különböző klasszikusainak ismerete az olvasás élményén túl normatív hozadékkal is jár. ${ }^{29}$

Ez különösen igaz a már említett Callwellre, aki a Brit Birodalom tisztjeként Kisháborúk, elvek és gyakorlat címü müvében részletesen elemzi ezen háborúk sajátosságait. Az angolban külön írt small war, azaz kisháború kifejezést szerinte a szükség szülte, és semmilyen módon nem áll kapcsolatban ezen háborúk méretével. A kisháborúk nagyon változatos képet mutatnak a hadjáratok jellege és körülményei vonatkozásában. Több formájuk létezik, úgymint vademberek és félcivilizált népek elleni expedíciók, lázadások és gerillák elnyomását szolgáló hadjáratok, valamint a nyílt csatát nem vállaló ellenfelek elleni hadműveletek. A kisháború csupán egy értelmezési keretet bizosít a reguláris erők irreguláris vagy irreguláris jelleget magán viselő erők elleni harcához. Magában foglalja a partizánellenes hadviselést, különböző lázadások

\footnotetext{
26 Thornton (2005) i. m. 43-44.

27 Kömlödi Ferenc: A futurológus elöre megmondta. Információs Társadalom, 2. (2002), 2. 85-86; Mihály Ildikó: Hullámtörés. Taní-tani online.

28 Alvin Toffler: The Third Wave. Bantam Books, 1981. 46-60.

29 Carl von Clausewitz: On War. Everyman's Library, 1993. 173.
} 
és felkelések leverését, barbár népek területének nagyhatalom általi megszállását, büntető hadjárat vezetését távoli gyarmatok határterületének törzsei ellen, irreguláris vagy gyengén felfegyverzett, felszerelt és vezetett erők elleni harcot, valamint olyan egyéb katonai tevékenységeket, amelyek körülményei különböznek a civilizált nemzetek modern, reguláris hadviselésétöl. ${ }^{30}$

A kisháború megvívásának körülményei Callwell szerint annyira változatos képet mutatnak, az ellenfél harceljárásai annyi sajátosságot tartalmaznak, a hadszíntér pedig annyi egyedi vonással bír, hogy az alapot képező irreguláris hadviselés teljes mértékben eltér a megszokottól. A háború múvészetét is meg kell változtatni annak érdekében, hogy minden egyes esetben megfeleljen a körülményeknek. A kisháborúk megvívása minden szempontból külön világot képvisel, amely ugyan nagymértékben különbözik a reguláris hadviseléstől, ennek ellenére számos ponton lehetővé teszi a nagy háborúval való összevetést. A kisháborúk jobb megértéséhez és vizsgálatához Callwell hármas osztályozást javasol, úgymint:

1. hódítási és megszállási céllal vezetett hadjáratok;

2. felkelések és törvénytelenségek leverése, valamint megszállt és csatolt területek békéltetése érdekében vezetett hadjáratok;

3. sértés megtorlása, igazságtalanság megbosszulása, vagy egy veszélyes ellenség megdöntése érdekében vezetett hadjáratok. ${ }^{31}$

Egyfajta negyedik osztályként említi még a szükségből megvívott háborút, amely különböző okok miatt törhet ki, de nem nagyon gyakori. Minden osztály olyan sajátos jegyeket mutat fel, amelyek befolyással bírnak a hadjáratokat alkotó hadműveletek alakulására. A hódítási és megszállási céllal vezetett hadjáratok idegen területen és olyan ellenségek ellen folynak, akik valamilyen hatalmasság vagy főnök vezetése alatt állnak. A legyőzendő erők pedig, legyenek bármennyire is irregulárisak, valósak és meghatározottak. A felkelések és törvénytelenségek leverése, valamint megszállt és csatolt területek békéltetése érdekében vezetett hadjáratok saját területen folynak, meghatározatlan erővel rendelkező gerillák és egyéb banditák ellen. Ezek a hadjáratok a legnehezebbek és egyben a legfárasztóbbak is a reguláris erők számára. Végrehajtásuk során két, egymástól jól elkülöníthető szakasz különböztethető meg. Az első szakasz a szervezett ellenállás letörése néhány ütközet eredményeként, a második pedig a szervezett ellenállás megszúnését követően a lesállásokból végrehajtott rajtaütések felszámolása és azok szigorú megtorlása. Azokon a területeken, amelyeken az összeköttetési útvonalak rosszak, és nem lehet megbízható információt szerezni, a legkellemetlenebb hadmüveletek alakulhatnak ki. Sértés megtorlása, igazságtalanság megbosszulása vagy egy veszélyes ellenség megdöntése érdekében vezetett hadjáratok hasonló jegyeket mutatnak a hódítási és megszállási céllal vezetett hadjáratokkal, azonban megkövetelik az ellenfél teljes legyőzését és erőinek szétzúzását. A szükségből megvívott háborúk politikai szándékból folynak, és minden tekintetben különböznek ez előző három osztály háborúitól. ${ }^{32}$

\footnotetext{
Callwell (1906) i. m. 21-22.

Callwell (1906) i. m. 23-24

Callwell (1906) i. m. 25-28.
} 
Callwell kiemeli, hogy a kisháborúk esetében az ellenfél erejének és harceljárásainak alapos tanulmányozása kiemelt fontossággal bír. Reguláris háború esetén mindkét fél tökéletesen tisztában van a másik képességeivel, a csatákat és ütközeteket pedig ismert szabályok szerint vívják meg. Kisháború esetén az ellenfél soha nem harcol kétszer ugyanazon a módon. A hadjáratok során a reguláris haderő katonája meglepő változatossággal találkozik mind hadászati, mind harcászati szinten. ${ }^{33}$ Ennek megfelelően szükséges az ellenfél viselkedésének, szokásainak, valamint eljárásainak lehető legalaposabb tanulmányozása nem csak a parancsnok és törzse, hanem minden beosztott tiszt számára. Minden kisháború új sajátosságot hordoz magában, amelyre a lehető legjobban fel kell készülni. A kisháborúval elérendő célok megválasztását nagymértékben meghatározzák a körülmények. A reguláris hadviselésben az ellenfelet a lakosság, a meglévő intézményrendszer, a központosított kormányzás és az egységesen vezetett haderő jeleníti meg. Az ilyen háború szokásos célja a főváros fenyegetése vagy lehetőség szerinti elfoglalása, mivel a fővárosban található a kormányzat és a törvényhozás. A főváros általában az összeköttetési útvonalak metszésében található, és emiatt a kereskedelem központja is egyben. Esetleges elfoglalása egyet jelent a végrehajtó hatalom megbénításával, a kereskedelem összeomlásával és a pénzügyi csőddel. ${ }^{34}$

A kisháborúban érintett országok fövárosai nem bírnak ilyen központi szereppel, mivel alapvetően csak az uralkodó és tanácsadói székhelyeként szolgálnak. Elfoglalásuk inkább jelent presztízsveszteséget, mint a lakosságot érintő valós és nehezen helyrehozható hátrányt. A kisháborúk esetében problémát jelent, hogy sok esetben nincs megdönthető uralkodó, elfoglalható főváros, megverhető haderö, nincsenek megszállható erősségek vagy nagy lakossági központok. Amennyiben az ellenfél nem befolyásolható közvetlenül a fegyverek alkalmazásával a hazafiasságán vagy a becsületén keresztül, Callwell szerint befolyásolható közvetetten az állatállománya elhajtásán, a vagyontárgyai elkobzásán, a terményei és takarmánya elpusztításán, valamint a falvai lerombolásán keresztül. Természetesen ez utóbbi lehetőség nem szerencsés, és a hosszú távú megbékélés megköveteli az irgalmasság és a keménység megfelelő vegyítését. A kisháború és a reguláris hadjáratok közötti legnagyobb különbség Callwell szerint abban rejlik, hogy az ellenséges haderő legyőzése nem feltétlenül képezi a fő erőkifejtés tárgyát. A kisháború esetében a morális hatás kiváltása sokszor fontosabb az anyagi győzelemnél. A hadmüveletek ezért korlátozott jellegüek, és csak a zavar keltésére és bizonyos fokú rombolásra terjednek ki. A körülmények változatos jellege okozza ezen háborúk összetettségét és sajátosságai nehezen kezelhetőségét. A reguláris erőknek kezdettől fogva sok ismeretlen tényezővel kell számolni, úgymint a kirobbanás idejének és helyének váratlansága vagy a hadszíntér nem feltárt területeken való elhelyezkedése miatt. Az ellenséges erő méretéről, erejéről, fegyverzetéről és harcértékéről, valamint a hadszíntér úthálózatáról és egyéb sajátosságairól általában csak hiányos információ áll rendelkezésre. ${ }^{35}$

Callwell használja a hadművelet kifejezést, de nem tesz említést hadműveleti szintről.

4 Callwell (1906) i. m. 29-30.

35 Callwell (1906) i. m. 30-32. 


\section{6. Összefoglalás}

A nemzetközi rendszer ciklikusságát erősíti, hogy Callwell kisháborúra vonatkozó leírása nagymértékben egyezik a 21. század első két évtizedében kirobbant konfliktusok föbb sajátosságaival. Természetesen könyvének szóhasználata nem felel meg a politikai korrektség elvének, egyes kijelentései pedig kifejezetten sértők. A korabeli brit harcszabályzatokat olvasva, amely külön fejezetben nevesíti a civilizálatan ellenség elleni hadviselést, ebben semmi meglepő vagy különös nincs. ${ }^{36}$

Callwell olvasása egyértelmü normatív hozadékkal bír, mivel előjön benne a szimmetrikus és az aszimmetrikus jelleg, alacsony és magas intenzitás, az állami és nem állami szereplők, a reguláris és irreguláris haderők, valamint a hagyományos és nem hagyományos hadviselés keveredése, egyfajta szürkezónás állapot kialakulása. A Callwell általa javasolt közvetett módszer, benne az állatállomány elhajtása, a vagyontárgyak elkobzása, a termények és takarmányok elpusztítása, valamint a falvak lerombolása a hangsúlyt az intézményi tér helyett a társadalmi és az egyéni térbe helyezi át. A 19. század kisháborúihoz hasonlóan a 21. század elejének kisháborúi is nagyon változatos képet mutatnak a hadjáratok jellege és körülményei vonatkozásában. Több formában jelentkeznek, a körülmények változatos képet mutatnak, az ellenfél harceljárásai annyi sajátosságot tartalmaznak, a hadszíntér pedig annyi egyedi vonással bír, hogy ezen háborúk megvívása továbbra is a legnehezebb, a legfárasztóbb, így a legkellemetlenebb hadműveletek közé tartoznak. Sok esetben nem vesz részt bennük egységes nemzetet alkotó lakosság, nincs meglévő intézményrendszer, központosított kormányzás és egységesen vezetett haderő. A kisháborúban egy alapvetően intézményi háborúra felkészíttet reguláris erő áll szemben egy társadalmi vagy egyéni háborút viselő ellenféllel. A haditechnika jelentette fizikai pusztításban meglévő előny áll szemben a pszichológiai eltökéltséggel. Ennek megfelelően a reguláris erőnek nyernie kell, míg az irregulárisnak elég, ha nem szenved vereséget. ${ }^{37}$

A kisháború kifejezés nemcsak az FM-ek és az AJP-k vonatkozásában nem használt, de a magyar katonai szakirodalomban sem nagyon terjedt el. A kisháborút címszóként, szócikként vagy utaló címszóként sem az 1995-ben, sem pedig a 2019-ben kiadott Hadtudományi Lexikon nem tartalmazza. ${ }^{38} \mathrm{~A} 20$. századi történelmi eseményeket figyelembe véve a kisháború kifejezést legtöbbször az 1939 tavaszán megvívott magyar-szlovák fegyveres konfliktussal kapcsolatban említik. A katonai szakirodalomban általában nem, vagy csak érintőlegesen szerepelnek ennek a konfliktusnak az eseményei, amelyet háborús cselekményekkel tarkított határkonfliktusnak vagy határkiigazításnak is szoktak nevezni. A magyar-szlovák fegyveres konfliktussal kapcsolatban nem lehet háborúról beszélni abban az értelemben sem, hogy a két állam között formailag soha nem került sor hadüzenet váltására, és a diplomáciai viszony sem szakadt meg. ${ }^{39}$

Field Service Regulations, Part I Operations. His Majesties' Stationary Office, 1912. 191-212.

Henry A. Kissinger: The Viet Nam Negotiations. Foreign Affairs, 48. (1969), 2. 214-226.

Szabó József (főszerk.): Hadtudományi Lexikon. Magyar Hadtudományi Társaság, 1995; Krajnc Zoltán (főszerk.): Hadtudományi Lexikon - Új Kötet. Budapest, Dialóg Campus, 2019.

39 Janek István: Az elfelejtett háború. A szlovák-magyar kis háború története 1939 márciusában. Történelmi Szemle, 42. (2001), 3-4. 299. 
A nemzetközi rendszer és a biztonsági kihívások ciklikussága megköveteli a kisháborúnak mint a háború egyik jellegzetes megjelenési formájának értelmezését és tudományos meghatározását. Fejlődésének és kortárs megjelenésének vizsgálata, fontosabb elméleti kérdéseinek elemzése és összegzése pedig a magyar hadtudomány szempontjából hiánypótló jelleggel is bír. A kisháború elmélete, gyakorlata és az azt befolyásoló tényezők ismerete a szerző véleménye szerint elengedhetetlen a kortárs háború főbb sajátosságainak jobb megértéséhez és sikeres megvívásához.

\section{Felhasznált irodalom}

1163/2020. (IV. 21.) Korm. határozat Magyarország Nemzeti Biztonsági Stratégiájáról. 1. sz. melléklet: Magyarország Nemzeti Biztonsági Stratégiája „Biztonságos Magyarország egy változékony világban" 2020. 2101-2118.

AJP-3.4.4 (A) Allied Joint Doctrine for Counter-Insurgency. NATO Standardization Agency, 2016.

AJP-3.4.4 Allied Joint Doctrine for Counterinsurgency (COIN). NATO Standardization Agency, 2011.

Bakos Csaba Attila: Hagyományostól eltérő hadviselés, hagyományostól eltérő vezetésszemlélet. Társadalom és Honvédelem, 19. (2015), 3. 41-52.

Boda Mihály: A kisháború etikája. In Harangi-Tóth Zoltán (szerk.): A „kisháborúk”és a könynyü csapatok harcászata (1792-1918). Elmélet, etika és a gyakorlat. Hadtörténelem egyetemi jegyzet. Budapest, Nemzeti Közszolgálati Egyetem, 2019. 7-50.

Callwell, C. E.: Small Wars, Their Principles and Practice. General Staff-War Office, 1906. Clausewitz, Carl von: On War. Everyman's Library, 1993.

Demarest, Geoff: Let's Take the French Experience in Algeria Out of U.S. Counterinsurgency Doctrine. Military Review, 88. (2010), 4. 19-24.

Ellis, John: The Social History of the Machine Gun. New York, Pantheon Books, 1975. Field Service Regulations, Part I Operations. His Majesties' Stationary Office, 1912.

FM 3-24/MCWP 3-33.5: Counterinsurgency. Headquarters, Department of the Army, Washington, 2006.

FM 3-24/MCWP 3-33.5: Insurgencies and Countering Insurgencies. Headquarters, Department of the Army, Washington, 2014.

Heneker, William C. G.: Bush Warfare - The Early Writings of General Sir William C.G. Heneker, KCMG, DSO. Edited with New Material and Introduction by Major Andrew B. Godefroy, Directorate of Land Concepts and Designs. Department of National Defence, Canada, 2009.

Heydte, Friedrich August Freiherr von der: Modern Irregular Warfare in Defense Policy and as a Military Phenomenon. New York, New Benjamin Franklin House, 1986.

Janek István: Az elfelejtett háború. A szlovák-magyar kis háború története 1939 márciusában. Történelmi Szemle, 43. (2001), 3-4. 299-313.

Jobbágy Zoltán: A felkelők elleni műveletekről: Egy elfeledett klasszikus: Bernardo de Vargas Machuca. Honvédségi Szemle, 141. (2013), 2. 15-18.

Jobbágy Zoltán: David Galula és a felkelés ellenes műveletek elmélete és gyakorlata francia megközelítésben. Hadtudományi Szemle, 10. (2017), 4. 82-97. 
Kissinger, Henry A.: The Viet Nam Negotiations. Foreign Affairs, 48. (1969), 2. 214-226. Online: https://doi.org/10.2307/20039369

Kömlödi Ferenc: A futurológus elöre megmondta. Információs Társadalom, 2. (2002), 2. 85-86. Online: https://doi.org/10.22503/inftars.II.2002.1.8

Kondratieff, Nikolai D.: The Long Waves in Economic Life. The Review of Economics and Statistics, 17. (1935), 6. 105-115. Online: https://doi.org/10.2307/1928486

Krajnc Zoltán (föszerk.): Hadtudományi Lexikon-Új Kötet. Budapest, Dialóg Campus, 2019.

Lt. Col. John Nagl on the U.S. Army/Marine Corps Counterinsurgency Field Manual. Online: www.youtube.com/watch?v=QuDlrrRDfUw

Mani, Krishnan S.: Jallianwala Bagh Massacre - Bitter Reminder of Indian History. South Asian Law and Economics Review, 3. (2018), november. 132-159.

Mihály Ildikó: Hullámtörés. Taní-tani online. Online: www.tani-tani.info/083mihaly

Modelski, George: The Long Cycle of Global Politics and the Nation-State. Comparative Studies in Society and History, 20. (1978), 2. 214-235. Online: https://doi.org/10.1017/ S0010417500008914

Morris, lan: War! What is it Good For? Conflict and Progress of Civilization from Primates to Robots. Farrar, Straus and Giroux, 2014.

Nemzeti Közszolgálati Egyetem Kutatási, Fejlesztési és Innovációs Stratégia 2016-2020. Budapest, Nemzeti Közszolgálati Egyetem, 2016.

Peterson, Terence: Myth-Busting French Counterinsurgency. War on the Rocks/Texas National Security Review, 2015. december 3. Online: https://warontherocks. com/2015/12/myth-busting-french-counterinsurgency/

Porkoláb Imre: Szervezeti adaptáció a Magyar Honvédségben: küldetésalapú vezetés 2.0 a digitális transzformáció korában. Honvédségi Szemle, 147. (2019), 1. 3-12.

Schmitt, Carl: The Theory of the Partisan, A Commentary/Remark on the Concept of the Political. Berlin, Duncker \& Humblot, 1963. 32-38. Online: http://obinfonet. ro/docs/tpnt/tpntrex/cschmitt-theory-of-the-partisan.pdf

Szabó József (főszerk.): Hadtudományi Lexikon. Magyar Hadtudományi Társaság, 1995.

Thornton, Rod: Historical Origins of the British Army's Counterinsurgency and Counterterrorist Techniques. In Theodor H. Winkler - Anja H. Ebnöther - Matts B. Hansson: Combating Terrorism and Its Implications for the Security Sector. Swedish National Defence College, 2005. 26-44.

Toffler, Alvin: The Third Wave. Bantam Books, 1981.

Tribes still matter, how global leaders tap into diaspora networks. The Economist, 2011. január 22. Online: www.economist.com/node/17928961

Ujházy László: Felkészítés a NATO összhaderőnemi kötelékei parancsnokságain rendszeresített beosztásokra. Honvédségi Szemle, 62. (2008), 1. 30-31. 